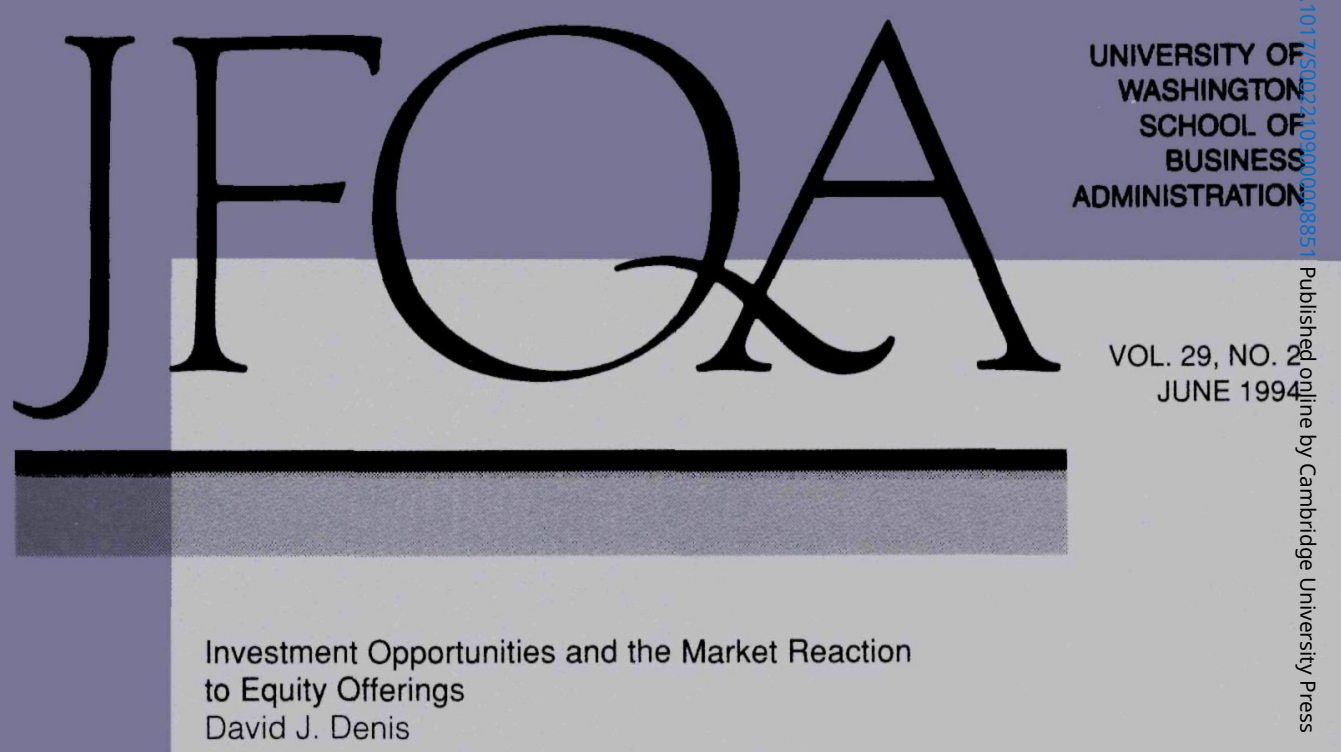

Optimal Maturity Structure with Multiple Debt Claims Joel F. Houston and S. Venkataraman

Leverage Constraints and the Optimal Hedging of Stock and Bond Options

Vasanttilak Naik and Raman Uppal

Securities Markets, Diffusion State Processes, and Arbitrage-Free Shadow Prices John Heaney and Geoffrey Poitras

Derivative Security Markets, Market Manipulation, and Option Pricing Theory

Robert A. Jarrow

The Individual Investor and the Weekend Effect Abraham Abraham and David L. Ikenberry

On the Efficiency of Least Squares Regression with Security Abnormal Returns as the Dependent Variable Imre Karafiath

Immunization in Markets with Tax-Clientele Effects: Evidence from the Canadian Market Eliezer Z. Prisman and Yisong Tian 
JOURNAL OF FINANCIAL AND QUANTITATIVE ANALYSIS

A PUBLICATION OF THE UNIVERSITY OF WASHINGTON

SCHOOL OF BUSINESS ADMINISTRATION

VOL. 29, NO. 2, JUNE 1994

Investment Opportunities and the Market Reaction

to Equity Offerings

David J. Denis

Optimal Maturity Structure with Multiple Debt Claims

Joel F. Houston and S. Venkataraman

Leverage Constraints and the Optimal Hedging of Stock

and Bond Options

Vasanttilak Naik and Raman Uppal

Securities Markets, Diffusion State Processes, and

Arbitrage-Free Shadow Prices

John Heaney and Geoffrey Poitras

Derivative Security Markets, Market Manipulation,

and Option Pricing Theory

Robert A. Jarrow

The Individual Investor and the Weekend Effect

Abraham Abraham and David L. Ikenberry

On the Efficiency of Least Squares Regression with Security

Abnormal Returns as the Dependent Variable Imre Karafiath

Immunization in Markets with Tax-Clientele Effects: Evidence

from the Canadian Market

Eliezer Z. Prisman and Yisong Tian 
MANAGING EDITORS

Jonathan Karpoff

ASSOCIATE EDITORS

\section{Gordon Alexander}

University of Minnesota

Paul Asquith

Massachusetts Institute of Technology

Michael Barclay

University of Rochester

Sanjai Bhagat

University of Colorado

Stephen Brown

New York University

Larry Dann

University of Oregon

Wayne Ferson

University of Washington

Sanford Grossman

University of Pennsylvania

Bruce Grundy

University of Pennsylvania

Lawrence Harris

University of Southern California

Campbell Harvey

Duke University

Robert Heinkel

University of British Columbia

John Hull

University of Toronto

Gregg Jarrell

University of Rochester

Robert Jarrow

Cornelt University
Paul Malatesta

Gautam Kaul
University of Michigan

Donald Keim

University of Pennsylvania

Robert Korajczyk

Northwestern University

Josef Lakonishok

University of Illinois

Francis Longstaff

University of California, Los Angeles

Ronald Masulis

Vanderbilt University

John McConnell

Purdue University

Robert McDonald

Northwestern University

Wayne Mikkelson

University of Oregon

Eduardo Schwartz

University of California, Los Angeles

Hans Stoll

Vanderbilt University

Rex Thompson

Southern Methodist University

Sheridan Titman

University of California, Los Angeles

Ralph Walkling

Ohio State University

Alan White

University of Toronto

\section{STAFF}

Martha Auvil

Editor

Susan Huot

Nicolette Roberge

Office Manager

Gloria Young

Editorial Associates

POSTMASTER: Send address changes to Journal of Financial and Quantitative Analysis, School of Business Administration, University of Washington, DJ-10, Seattle, Washington 98195.

Second class postage is paid at Seattle, Washington.

Copyright 1994, School of Business Administration, University of Washington.

Journal of Financial and Quantitative Analysis - ISSN 0022-1090. 
JOURNAL OF FINANCIAL AND QUANTITATIVE ANALYSIS

UNIVERSITY OF WASHINGTON

SCHOOL OF BUSINESS ADMINISTRATION

PHONE: (206) 543-4598 FAX: (206) 543-6872 E-MAIL: jfqa@u.washington.edu

VOL. 29, NO. 2, JUNE 1994

\section{PURPOSE AND FOCUS}

The Journal of Financial and Quantitative Analysis (JFQA) is published quarterly in March, June, September, and December by the School of Business Administration at the University of Washington in Seattle, Washington U.S.A.

The JFQA publishes theoretical and empirical research in financial economics. Topics include corporate finance, investments, capital and security markets, and quantitative methods of particular relevance to financial researchers.

Opinions expressed in the JFQA are those of the authors and do not necessarily reflect those of the School of Business Administration at the University of Washington.

For specific information concerning subscriptions, submissions, single-copy orders, missing issues, permission to reprint, or advertising, write, call, fax, or e-mail the JFQA office.

\section{SUBMISSIONS}

It is JFQA policy to give prompt attention to all submitted manuscripts. Consistent with this policy, honoraria are paid to referees who provide timely reviews.

Manuscripts are to be sent in quadruplicate with a $\$ 100$ submission fee for subscribers ( $\$ 140$ for nonsubscribers) to Professor Paul Malatesta, Managing Editor. Checks must be payable to the JFQA in U.S. dollars for deposit in a U.S. bank. VISA and MasterCard are accepted. Style guides for preparing manuscripts can be found on one of the back pages of each JFQA issue.

\section{SUBSCRIPTIONS}

Subscriptions, which must be prepaid and renewed annually, start with the next available issue unless otherwise requested. Checks or money orders must be payable to the JFQA in U.S. dollars for deposit in a U.S. bank. VISA and MasterCard are accepted. Claims for missing issues must be made within 6 months of the date of publication.

Annual Subscription Fees:

Library or Firm

Outside U.S.A.

Individual

Outside U.S.A.

Student (with verification)

Outside U.S.A.

Airmail (additional)
U.S. $\$ 85$

U.S. $\$ 90$

U.S. $\$ 40$

U.S. $\$ 45$

U.S. $\$ 25$

U.S. $\$ 30$

U.S. $\$ 30$ 